\title{
Oxygen Reduction on Au(100)-like Polycrystalline Gold Electrode in Alkaline Solution
}

\author{
Irina Srejić ${ }^{1}$, Milutin Smiljanić ${ }^{1}$, Zlatko Rakočević ${ }^{1}$, Svetlana Štrbac ${ }^{2, *}$ \\ ${ }^{1}$ INS Vinča, Laboratory of Atomic Physics, University of Belgrade, Mike Alasa 12-14, \\ 11001 Belgrade, Serbia \\ ${ }^{2}$ ICTM-Institute of Electrochemistry, University of Belgrade, Njegoševa 12, 11000 Belgrade, Serbia \\ *E-mail: $\underline{\text { sstrbac@tmf.bg.ac.rs }}$
}

doi: $10.20964 / 2016.12 .51$

Received: 17 September 2016 / Accepted: 10 October 2016 / Published: 10 November 2016

Catalytic properties of polycrystalline gold, $\mathrm{Au}(\mathrm{poly})$, were examined for the oxygen reduction reaction in alkaline solution using the rotating disc electrode technique. On electrochemically prepared $\mathrm{Au}($ poly), oxygen reduction proceeds partly through 4e-reaction pathway resembling the activity of bare $\mathrm{Au}(100)$ in alkaline solution. Electrochemical behavior of such $\mathrm{Au}(100)$-like polycrystalline gold electrode was compared with bare $\mathrm{Au}(100)$ surface, as well as with stepped $\mathrm{Au}(210)=\mathrm{Au}[2(100) \times(110)]$ and $\mathrm{Au}(533)=\mathrm{Au}[4(111) \times(100)]$ surfaces. It is shown that polycrystalline gold electrode behaved in a similar manner as stepped $\mathrm{Au}[\mathrm{n}(111) \mathrm{x}(100)]$ surfaces, meaning that the enrichment in (111) $\mathrm{x}(100)$ steps, rather than in (100) orientation is responsible for a partial 4e-reaction pathway in alkaline solution.

Keywords: Au(poly), Au(100), AFM, RDE, oxygen reduction, alkaline solution

\section{$\underline{\text { FULL TEXT }}$}

(C) 2016 The Authors. Published by ESG (www.electrochemsci.org). This article is an open access article distributed under the terms and conditions of the Creative Commons Attribution license (http://creativecommons.org/licenses/by/4.0/). 